\title{
ANALISIS SISTEM SANITASI DASAR DI PERMUKIMAN PESISIR PULAU PENYENGAT
}

\author{
${ }^{1}$ Hendro Murtiono, ${ }^{2}$ G Gusti Ngurah Anom Gunawan, ${ }^{3}$ Carissa Dinar Aguspriyanti, ${ }^{4}$ Tabitha \\ Nailah Putri, ${ }^{5}$ Rilsha Nadya Dwi Poetri Z
}

1-5 Universitas Internasional Batam, Batam, Indonesia tabithanailah2001@gmail.com

Informasi Naskah

Diterima: 1/10/2021; Disetujui terbit: 16/12/2021; Diterbitkan: 31/12/2021;

http://journal.uib.ac.id/index.php/jad

\begin{abstract}
ABSTRAK
Sanitasi dasar merupakan sarana dan prasarana minimal yang harus dimiliki oleh setiap hunian. Fasilitas-fasilitas yang termasuk dalam sanitasi dasar meliputi penyediaan air bersih, pembuangan air limbah, saluran drainase, dan pengelolaan sampah. Buruknya kualitas sanitasi dasar dapat menyebabkan kekumuhan di suatu permukiman. Sayangnya, fenomena tersebut terlihat pada beberapa permukiman pesisir di Kepulauan Riau yang notabene memiliki potensi sebagai desitinasi wisata budaya. Oleh karena itu, penelitian kualitatif ini bertujuan untuk menganalisis ketersediaan dan kondisi sanitasi dasar di Kampung Datuk, Pulau Penyengat, Kota Tanjung Pinang, Kepulauan Riau. Observasi lapangan dilakukan untuk memperoleh data primer. Hasil penelitian mengungkapkan bahwa warga kampung ini masih menyalurkan air limbah dan drainase langsung ke laut. Meski dianggap belum memenuhi standar sanitasi dasar yang baik secara menyeluruh, permukiman pesisir Kampung Datuk di Pulau Penyengat telah cukup sadar untuk mengelola sampah dengan baik dan juga telah tersedia sarana air bersih yang cukup untuk memenuhi kebutuhan warga sehari-hari. Oleh karena itu, penulis memberikan beberapa rekomendasi dalam penelitian ini, khususnya yang berkaitan dengan sistem pembuangan air limbah dan saluran drainase di permukiman tersebut.
\end{abstract}

Kata Kunci: sanitasi dasar, permukiman pesisir, Pulau Penyengat

\section{ABSTRACT}

Basic sanitation is the minimum facilities and infrastructure that must be owned by every dwelling. The facilities contained in basic sanitation include the clean water supply, waste water disposal, drainage channels, and waste management. Poor quality of basic sanitation can cause slums in a settlement. Unfortunately, this phenomenon can be seen in several coastal settlements in the Riau Islands which actually have the potential as a cultural tourism destination. Therefore, this qualitative study aims to analyse the availability and conditions of basic sanitation in Datuk Village, Penyengat Island, Tanjung Pinang City, Riau Islands. Field observations were carried out to obtain primary data. The results of this study revealed that the residents of this village still dispense waste water and drainage directly into the sea. Although it is considered not to have met basic good sanitation standards as a whole yet, the coastal settlements of Kampung Datuk on Penyengat Island has been adequately aware to manage waste properly and have adequate clean water facilities to meet the daily needs of residents. Therefore, the author provides several recommendations in this study, especially those related to the sewerage system and drainage channels in the settlement.

Keywords: basic sanitation, coastal settlement, Penyengat Island 


\section{Pendahuluan}

Sebagai salah satu pilihan destinasi wisata, Pulau Penyengat merupakan pulau kecil yang dapat ditemukan sekitar dua kilometer dari Kota Tanjung Pinang, Kepulauan Riau. Dengan panjang 2,000 m dan lebar $850 \mathrm{~m}$, pulau ini berjarak sekitar 35 kilometer dari Pulau Batam. Pulau Penyengat telah lama dikenal sebagai pulau dengan warisan budaya Melayu yang mempesona, bahkan pulau ini pernah menjadi bagian tentatif dari World Heritage dengan berbagai macam peninggalan cagar budaya yang dapat ditemukan di sana (Balai Pelestarian Cagar Budaya Sumatera Barat, 2020). Selain itu, potensi kebudayaan dari pulau ini dapat ditemukan pada kehidupan permukiman pesisirnya yang terbentuk dari sebuah perjalanan historis. Terdapat enam fase pertumbuhan permukiman pesisir di Pulau Penyengat yang memberikan pengaruh terhadap konfigurasi ruang, lingkungan binaan, dan kondisi geomorfologi fisiknya (Rijal et al., 2018).

Wilayah permukiman pesisir di Pulau Penyengat bisa dikatakan cukup terjaga. Namun, sama halnya dengan permukiman pesisir lain yang ada di Kepulauan Riau, kualitas permukiman pesisir di pulau tersebut beresiko menurun akibat kekumuhan. Salah satu faktor penyebab kumuhnya suatu permukiman adalah nihilnya sistem sanitasi yang baik (Aguspriyanti et al., 2020; Damisi et al., 2014; Pigawati, 2015; Sekatia, 2015). Beberapa daerah di Kepulauan Riau terutama Tanjung Pinang ternyata juga masih memiliki kondisi sanitasi yang belum optimal. Tanjung Unggat, Kelurahan TPI Barat, dan Kelurahan KP Baru merupakan beberapa daerah dengan sanitasi yang dinilai belum optimal dan masuk ke dalam wilayah cakupan Strategi Sanitasi Kota yang nantinya akan menjadi rujukan perencanaan pembangunan sanitasi kota Tanjung Pinang.Jika sistem sanitasi masih belum efektif, maka tentu saja akan membawa dampak negatif bagi berbagai aspek dalam lingkungan hidup sekitarnya, seperti resiko terkena penyakit yang ditularkan melalui air.

Purnama (2018) menyebutkan dalam diktatnya terkait pernyataan World Bank Water Sanitation Program (WSP) yang menegaskan bahwa Indonesia berada di urutan kedua di dunia sebagai negara yang memiliki sistem sanitasi buruk. la juga menambahkan bahwa berdasarkan data Perserikatan Bangsa-Bangsa (PBB), lebih dari 60 juta masyarakat Indonesia tidak memiliki sanitasi yang memadai sehingga beberapa di antaranya harus buang air besar tidak pada tempat seharusnya. Melihat kondisi tersebut, penelitian ini bertujuan untuk mengevaluasi sampai sejauh mana ketersediaan dan kondisi fasilitas sanitasi dasar di wilayah permukiman pesisir Pulau Penyengat. Diharapkan penelitian ini dapat memberikan gambaran untuk menentukan langkah yang tepat dalam meningkatkan mutu sanitasi, demi kualitas hidup masyarakat pesisir Pulau Warisan Budaya Melayu yang lebih baik.

\section{Kajian Pustaka}

\subsection{Permukiman Pesisir}

Berdasarkan Undang-Undang Nomor 4 tahun 1992, permukiman ialah salah satu bagian lingkungan hidup, dapat berupa wilayah perkotaan ataupun pedesaan yang mempunyai fungsi sebagai area tempat tinggal dan area aktivitas yang mengakomodasikan kehidupan (Pemerintah Indonesia, 1992). Sedangkan, menurut Hadi Sabari Yunus (1987) permukiman merupakan lingkungan buatan manusia atau alami untuk menetap sementara ataupun permanen dengan dilengkapi oleh fasilitas yang dapat dimanfaatkan oleh manusia secara kelompok maupun perseorangan. Djemabut menambahkan bahwa permukiman adalah kawasan lingkungan yang dilengkapi dengan 
fasilitas umum dan sosial yang selaras dengan kehidupan masyarakat (Blaang, 1977). Dengan kata lain, pemukiman juga memberikan ruang gerak dan pelayanan untuk meningkatkan kualitas hidup warga dengan memiliki fungsi sebagai fasilitas kegiatan kehidupan sosial, budaya dan ekonomi.

Definisi wilayah pesisir bisa berbeda-beda. Sesuai dengan Undang-Undang Nomor 27 tahun 2007, kawasan pesisir diartikan sebagai kawasan peralihan antara darat dan laut yang dipisah oleh 12 mil batas kawasan ke arah perairan dan batas kota kearah pedalaman (Pemerintah Indonesia, 2007). Sedangkan menurut kesepakatan dunia, kawasan pesisir ialah suatu kawasan peralihan antara daratan dan lautan. Dengan demikian dapat disimpulkan bahwa permukiman pesisir adalah suatu lingkungan hunian di perbatasan antara lautan dan daratan yang mempunyai sarana dan prasarana umum untuk menunjang kehidupan sosial, budaya, dan ekonomi masyarakatnya.

\subsection{Sistem Sanitasi Dasar}

Istilah dari "sanitasi" mengacu pada dukungan keadaan steril melalui pengolahan sampah dan air limbah. Menurut Widyati dan Yuliahsih (2002), sanitasi merupakan suatu upaya pencegahan penyakit dan memprioritaskan pada peningkatan kehidupan yang sehat bagi masyarakat. Badu (2012, dalam Auvaria \& Nilandita, 2018) menambahkan bahwa sanitasi dasar ialah sistem sanitasi yang minimal harus dimiliki oleh setiap keluarga sebagai syarat kesehatan lingkungan untuk menjalani kehidupan sehari-hari. Sanitasi dasar di sini meliputi penyediaan air bersih, pembuangan air limbah, saluran drainase, dan pengelolaan sampah (Celesta \& Fitriyah, 2019; Ramadhan, 2021).

- Ketersediaan air bersih dimanfaatkan untuk memenuhi kebutuhan air, baik domestik maupun non-domestik. Suatu wilayah wajib memiliki sarana penyediaan air bersih untuk masyarakat setempat (Agustin et al., 2016).

- Selain dari limbah dapur, sistem pembuangan air limbah juga memperhatikan pembuangan limbah kotoran manusia. Pembuangan kotoran manusia haruslah disalurkan ke tempat atau jamban yang memenuhi syarat kesehatan. Adapun kriteria jamban sehat yang disebutkan oleh Rohmah dan Syahrul (2017) antara lain infrastruktur jamban memiliki penutup, terdapat lantai dan tempat berpijak yang kuat dan tidak licin, tidak menimbulkan bau, tidak terlihat kotoran, jarak jamban kurang lebih 10 meter, tidak dapat dijamah oleh hewan seperti serangga, dan tersedianya alat pembersih.

- Sistem drainase mengacu pada kegiatan mengalirkan air, baik air permukaan maupun air tanah dari suatu area atau kawasan (Fairizi, 2015). Suatu permukiman haruslah memiliki sistem drainase yang baik agar mampu mengurangi kelebihan air sehingga tidak menimbulkan genangan atau bahkan banjir yang dapat mengganggu kesehatan dan kehidupan penduduknya.

- Pengelolaan sampah meliputi penyimpanan, pengumpulan dan pemusnahan sampah yang dilakukan sedemikian rupa sehingga sampah tidak mengganggu kesehatan masyarakat dan lingkungan hidup.

\section{Metode Penelitian}

Metode yang digunakan pada penelitian ini merupakan metode kualitatif deskriptif di mana data dikumpulkan dan fenomena yang terjadi dianalisis kemudian dijelaskan secara deskriptif (Anggito \& Setiawan, 2018). Penelitian ini menitikberatkan kepada aspek fisik dari sistem sanitasi dasar di permukiman pesisir Pulau Penyengat, antara lain penyediaan air bersih, pembuangan air limbah, saluran drainase, dan pengelolaan sampah. Dengan 
demikian, teknik yang digunakan dalam pengumpulan data ialah observasi lapangan secara langsung. Selain itu, data sekunder dan berbagai referensi lainnya didapatkan melalui beberapa jurnal dan juga teori-teori dari para ahli (Gunawan, 2013).

Wilayah penelitian berada di kawasan Kampung Datuk, Pulau Penyengat (lihat Gambar 1). Aspek yang akan ditinjau dalam penelitian ini adalah ketersediaan dan kondisi dari sanitasi dasar yang ada di permukiman pesisir tersebut. Metode purposive sampling ditentukan dengan mempertimbangkan sampel mana yang dinilai paling sinkron dan dianggap dapat mempresentasikan suatu populasi.

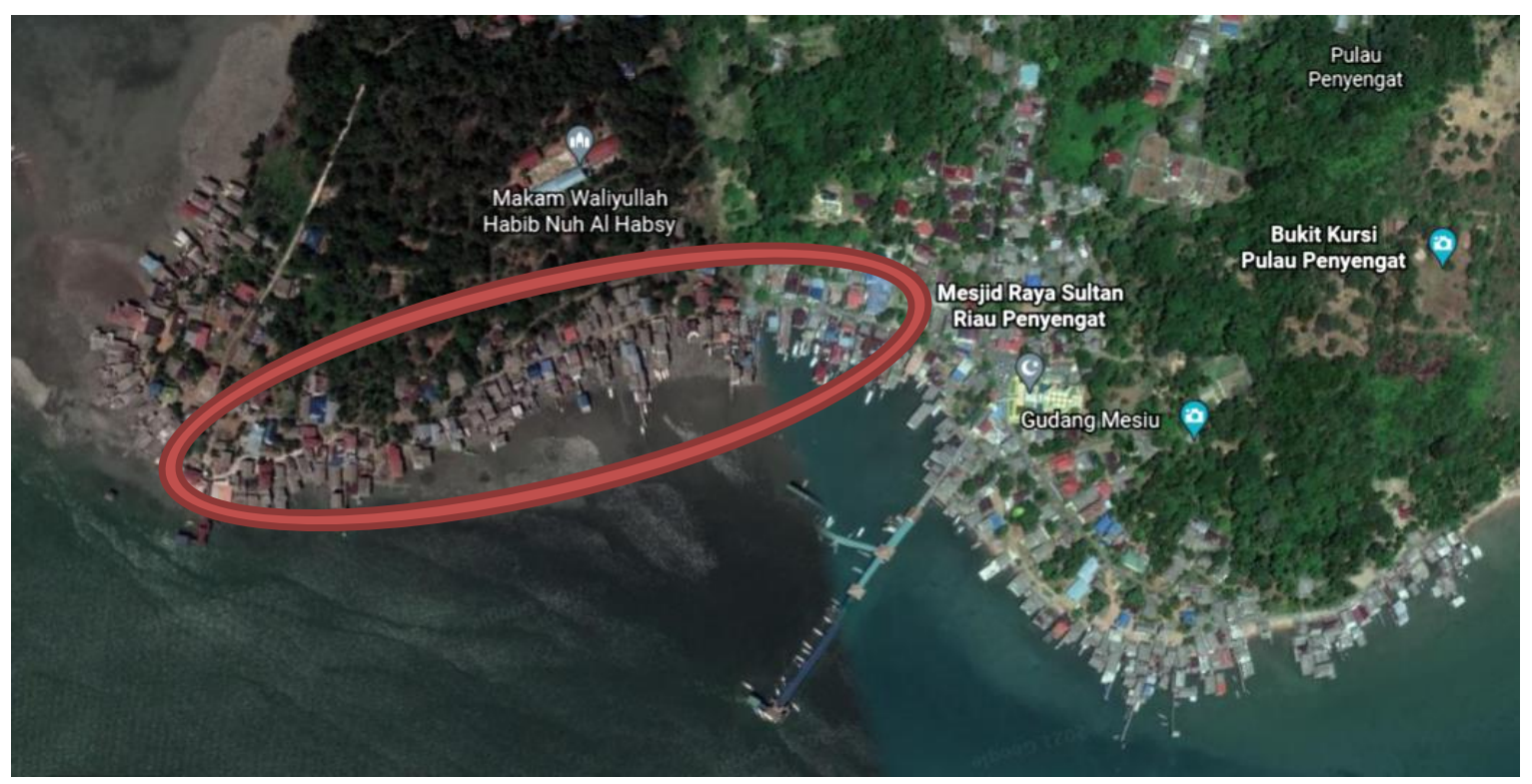

Gambar 1. Wilayah Penelitian: Kampung Datuk, Pulau Penyengat, Kepulauan Riau Sumber: Google Maps, 2021

\section{Hasil dan Pembahasan}

Berdasarkan hasil observasi, dapat dievaluasi bahwa ketersediaan dan kondisi sarana dan prasarana sistem sanitasi dasar di Pulau Penyengat khususnya di Kampung Datuk sudah cukup baik, walaupun perlu adanya peningkatan di beberapa aspek (lihat Tabel 1).

Tabel 1. Ketersediaan dan Kondisi Sistem Sanitasi Dasar di Kampung Datuk, Pulau Penyengat

\begin{tabular}{|c|c|c|c|l|}
\hline No & Aspek & & \multicolumn{3}{|c|}{ Deskripsi } & $\begin{array}{l}\text { Air bersih berasal dari } \\
\text { perigi yang digunakan } \\
\text { secara bersama, } \\
\text { namun ada yang } \\
\text { memiliki sumur } \\
\text { pribadi. }\end{array}$ \\
\hline 1 & Air bersih & & &
\end{tabular}




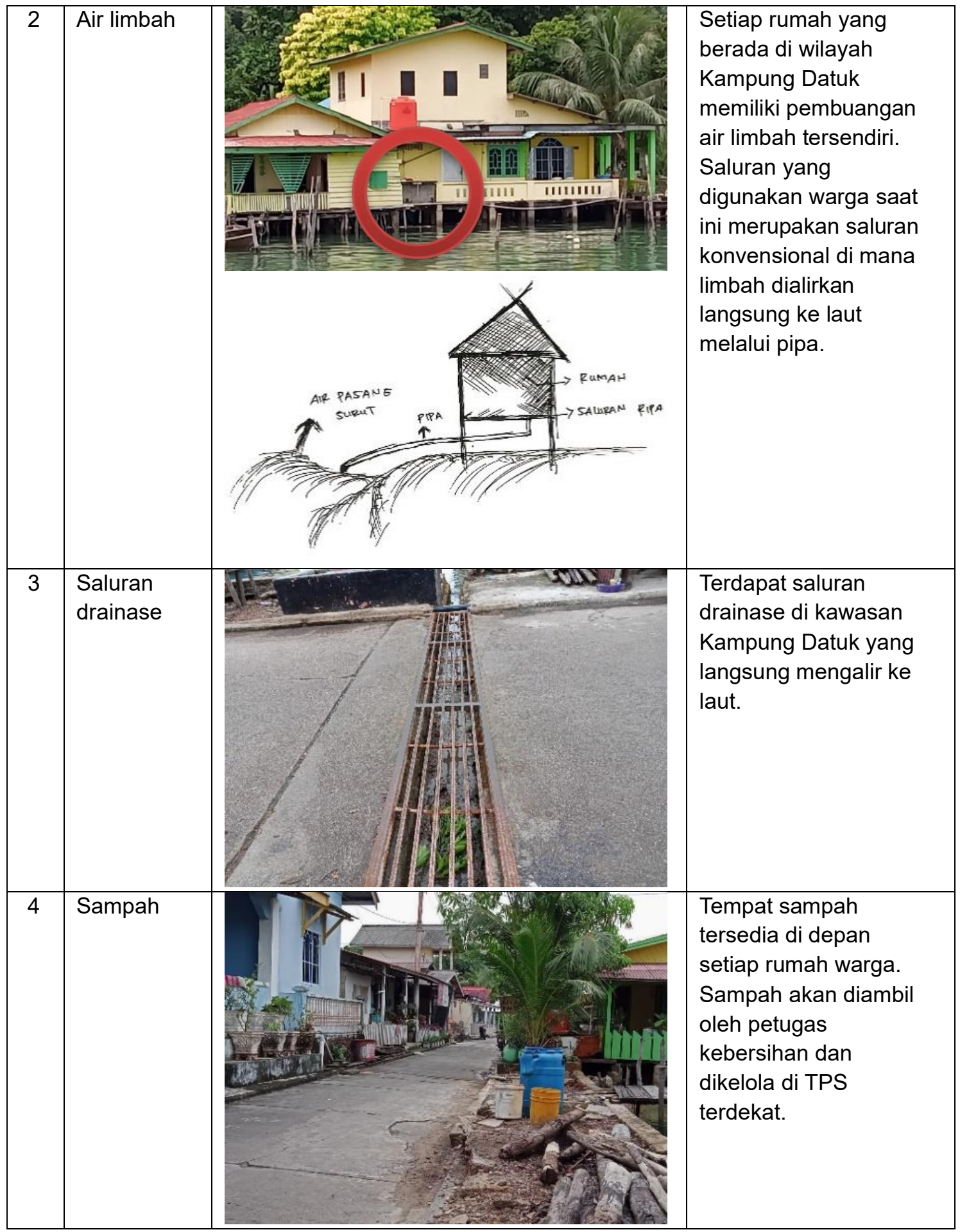

Sumber: Penulis, 2021

\subsection{Penyediaan Air Bersih}

Sumber ketersediaan air bersih diperoleh warga dari perigi yang digunakan secara Bersama. Tidak hanya satu, terdapat beberapa perigi yang masih bisa digunakan, di antaranya Perigi Umum, Perigi Puteri, dan Perigi Tua. Namun, untuk sementara ini sudah ada sebagian rumah penduduk yang memiliki sumur pribadi. Untuk air minum, terdapat Sistem Penyedian Air Minum (SPAM). Pemerintah daerah bertanggung jawab dalam peningkatan SPAM untuk memenuhi kebutuhan air minum warga dengan memenuhi syarat kualitas, kualitas, dan kontinuitas. 


\subsection{Pembuangan Air Limbah}

Pada umumnya masyarakat Pulau Penyengat membuang limbah yang berasal dari wc langsung menuju laut. Saluran yang mengarah langsung ke laut ini digunakan oleh warga karena biaya yang lebih murah dibandingkan dengan menggunakan septic tank tripikon-s yang membutuhkan biaya besar. Akan tetapi, perlu diketahui bahwa limbah dari tinja manusia berbahaya bagi kesehatan masyarakat. Bakteri E. Colli yang terdapat dalam limbah ini dapat mengakibatkan penyakit seperti kolera, diare, tipes. Selain berbahaya bagi kesehatan, limbah ini juga memberikan dampak buruk bagi ekosistem sekitar, terutama laut. Tinja manusia mengandung nutrien, yang mana jika masuk ke dalam air laut dalam jumlah besar akan menyebabkan peningkatan tumbuhnya ganggang. Pertumbuhan ganggang ini dapat mengakibatkan zona laut mati, yaitu matinya ikan dan tumbuhan laut karena ganggang menghabiskan oksigen yang ada di laut.

\subsection{Saluran Drainase}

Sama halnya dengan pembuangan dari toilet, air limbah yang berasal dari dapur dan cuci juga dibuang langsung ke laut. Bukan hanya rumah yang bermukim di atas laut, rumah yang berada di daratan juga menyalurkan air limbah cuci langsung ke laut. Saluran drainase untuk mengalirkan air limbah dibuat melintang di bawah jalan. Hal ini memberikan dampak negatif bagi lingkungan. Air yang berasal dari cucian dan dapur mengandung senyawa kimia yang dapat mencemari ekosistem yang berada di dalam laut.

\subsection{Pengelolaan sampah}

Permukiman pesisir di Pulau Penyengat bisa dikatakan permukiman yang bersih dari sampah. Sampah rumah tangga dikumpulkan warga di depan halaman yang akan diangkut oleh petugas kebersihan. Begitu pula dengan sampah yang ada di laut, petugas kebersihan akan membersihkannya setiap minggu dengan menggunakan perahu kecil.

\section{Kesimpulan}

Hasil penelitian mengindikasikan bahwa sistem sanitasi dasar di permukiman pesisir Pulau Penyengat, khususnya Kampung Datuk, sudah cukup baik walaupun masih ada beberapa aspek yang perlu ditingkatkan, dengan rincian sebagai berikut:

- Ketersediaan air bersih terjaga dengan banyaknya perigi yang terdapat di sana. Begitu juga dengan air minum, pemerintah sudah berusaha memenuhi kebutuhan air minum masyarakat setempat dengan menyediakan SPAM.

- Sistem pembuangan air limbah merupakan contoh permasalahan sanitasi dasar di permukiman ini yang perlu diperbaiki. Air limbah masih disalurkan langsung ke laut yang mana berdampak negatif baik bagi kesehatan maupun lingkungan sekitar.

- Untuk saluran drainase, kawasan permukiman ini juga masih menyalurkannya langsung ke laut.

- Dengan pengelolaan sampah yang tersistem dengan baik, permukiman pesisir di Pulau Penyengat terutama di Kampung Datuk ini termasuk permukiman yang bersih.

Berdasarkan permasalahan di atas, penulis dapat memberikan rekomendasi untuk meningkatkan mutu sanitasi dasar di permukiman pesisir tersebut antara lain:

- Masyarakat dapat membuat septic tank yang cocok digunakan untuk permukiman yang berada di daerah perairan yakni tripikon-s di mana septic tank ini ditanam di dasar laut. Septic tank tripikon-s ini sangat membantu untuk tidak menimbulkan pencemaran 
seperti penggunaan saluran konvensional dengan menghadirkan septic tank vertikal dengan tiga pipa utama.

- Saluran drainase yang langsung mengalir ke laut bisa digantikan dengan Rotating Biological Contactor (RBC) yang merupakan suatu sistem pengendalian limbah cair dengan memakai metode unit pengendalian air limbah berotasi dengan pusat sumbu atau yang dapat digerakkan oleh motor drive system dan/atau tiupan udara (air drive system) difusser yang dibenam dalam air limbah, di bawah media. Keunggulan dari sistem pengolahan ini adalah operasional mudah, less energy, dan lumpur sisa yang dihasilkan lebih sedikit.

\section{Daftar Pustaka}

Aguspriyanti, C. D., Nimita, F., \& Deviana. (2020). Analisis Faktor-Faktor Penyebab Kekumuhan di Permukiman Pesisir Kampung Tua Tanjung Riau. Journal of Architectural Design and Development, 01(02), 176-186. https://doi.org/10.37253/jad.v1i2.1501

Agustin, I., Sari, N., Karim, A., Supit, C. J., \& Hendratta, L. A. (2016). Perencanaan Sistem Penyediaan Air di Desa Motongkad Utara Kecamatan Nuangan Kabupaten Bolaang Mongondow Timur. Jurnal Sipil Statik, 4(11), 705-714.

Anggito, A., \& Setiawan, J. (2018). Metodologi penelitian kualitatif. CV Jejak (Jejak Publisher).

Auvaria, S. W., \& Nilandita, W. (2018). Pemetaan Kondisi Sanitasi Dasar Eksisting di RT 02 RW 05 Kelurahan Jemur Wonosari Kota Surabaya, JawaTimur (Mapping of Existing Basic Sanitation Condition in RT 02 RW 05 Jemur Wonosari Sub-District, Surabaya City, East Java). Seminar Nasional Kota Berkelanjutan, 1(1), 195. https://doi.org/10.25105/psnkb.v1i1.2899

Balai Pelestarian Cagar Budaya Sumatera Barat. (2020). PULAU PENYENGAT: SURGA WARISAN BUDAYA MELAYU. Berita. https://kebudayaan.kemdikbud.go.id/bpcbsumbar/pulau-penyengat-surga-warisanbudaya-melayu/

Blaang, D. (1977). Perumahan dan Permukiman. Yayasan Obor Indonesia.

Celesta, A. G., \& Fitriyah, N. (2019). GAMBARAN SANITASI DASAR DI DESA PAYAMAN, KABUPATEN BOJONEGORO TAHUN 2016. Jurnal Kesehatan Lingkungan, 11(2), 83. https://doi.org/10.20473/jkl.v11i2.2019.83-90

Damisi, D. M., Kumurur, V. A., \& Sela, R. L. E. (2014). ANALISIS FAKTOR-FAKTOR KEKUMUHAN KAWASAN PERMUKIMAN PESISIR TRADISIONAL (Studi Kasus : Desa Bajo Kecamatan Tilamuta, Kabupaten Boalemo Provinsi Gorontalo). Sabua, 6(1), 163172.

Fairizi, D. (2015). Analisis Dan Evaluasi Saluran Drainase Pada Kawasan Perumnas Talang Kelapa Di Subdas Lambidaro Kota Palembang. Jurnal Teknik Sipil Dan Lingkungan, 3(1), 755-765.

Gunawan, I. (2013). KUALITATIF Imam Gunawan. Pendidikan, 143.

Pemerintah Indonesia. (1992). Undang-Undang Nomor 4 Tahun 1992 tentang Perumahan dan Permukiman. Lembaran Negara Republik Indonesia Tahun 1992 Nomor 23.

Pemerintah Indonesia. (2007). UNDANG-UNDANG REPUBLIK INDONESIA NOMOR 27 
TAHUN 2007 TENTANG PENGELOLAAN WILAYAH PESISIR DAN PULAU-PULAU KECIL (Issue 27). http://bk.menlh.go.id/files/UU_no_27_th_2007.pdf

Pigawati, R. N. B. (2015). Kajian Karakteristik Kawasan Pemukiman Kumuh Di Kampung Kota (Studi Kasus: Kampung Gandekan Semarang). Teknik Perencanaan Wilayah Kota, 4(2), 267-281.

Purnama, S. G. (2018). Diktat Dasar Kesehatan Lingkungan.

Ramadhan, W. K. (2021). Penilaian Risiko Kesehatan Lingkungan dan Pemetaan Kondisi Sanitasi Dasar di Desa Loji Jatiwangi Majalengka Jawa Barat Menggunakan Sistem Informasi Geografis (SIG) [Universitas Bakrie]. http://repository.bakrie.ac.id/4543/

Rijal, M., Setioko, B., \& Sardjono, A. B. (2018). Pertumbuhan Permukiman Pesisir di Pulau Penyengat. Seminar Nasional 3: Kearifan Lokal Dalam Keberagaman Untuk Pembangunan Indonesia, 1-6.

Rohmah, N., \& Syahrul, F. (2017). Relationship Between Hand-washing Habit and Toilet Use with Diarrhea Incidence in Children Under Five Years. Jurnal Berkala Epidemiologi, 5(1), 95. https://doi.org/10.20473/jbe.v5i12017.95-106

Sekatia, A. (2015). KAJIAN PERMUKIMAN KUMUH DAN NELAYAN TAMBAK LOROK SEMARANG Studi Kasus Partisipasi Masyarakat. Modul, 15(1), 57-66. https://doi.org/10.14710/mdl.15.1.2015.57-66

Widyati, R., \& Yuliahsih. (2002). Hygiene dan Sanitasi Umum dan Perhotelan. PT Gramedia Widiarsana Indonesia, Jakarta.

Yunus, H. S. (n.d.). STRUKTUR TATA RUANG KOTA. Pustaka Pelajar. 